\title{
A high-throughput approach to lanthanide complexes and their rapid screening in the ring opening polymerisation of caprolactone
}

\author{
Francesca M. Kerton,* Adrian C. Whitwood and Charlotte E. Willans \\ Department of Chemistry, University of York, Heslington, York, UK YO10 5DD. \\ E-mail:fmk1@york.ac.uk
}

Received 6th May 2004, Accepted 9th June 2004

First published as an Advance Article on the web 30th June 2004

\begin{abstract}
Libraries of lanthanide complexes supported by nitrogen and oxygen containing ligands have been synthesised using a high-throughput approach. The complexes were employed in the ring-opening polymerisation of $\varepsilon$-caprolactone, in some cases giving polycaprolactone of controlled molecular weight and narrow polydispersity. The libraries, based on twentyone ligands and eight lanthanide reagents, were developed in order to determine the best combination of lanthanide metal and ligand. They were prepared via transamination reactions of $\left[\mathrm{Ln}\left\{\mathrm{N}\left(\mathrm{SiMe}_{3}\right)_{2}\right\}_{3}\right]$ complexes with tetradentate dianionic ligands containing oxygen and nitrogen donors. ${ }^{1} \mathrm{H}$ NMR spectroscopy was used to screen polymerisation activity. The steric demand of the ligand has a significant effect on the polymerisation process, as do the type of nitrogen donor and the size of the central $\mathrm{Ln}^{3+}$ ion. Ligands containing aryl rings with bulky substituents such as tert-pentyl groups afforded species capable of performing controlled polymerisation of caprolactone, whereas less bulky groups such as methyl were not effective. Yttrium and mid-sized lanthanides such as samarium showed increased activity compared with the larger lanthanides, lanthanum and praseodymium, and the smaller lanthanides like ytterbium. X-ray crystal structures of a sterically demanding chelating amine-bis((2-hydroxyaryl)methyl) ligand (1) and a chloride bridged dinuclear gadolinium complex (2) are reported. The centrosymmetric molecule (2) contains gadolinium in distorted capped trigonal prismatic environments bonded to two amine, two phenolate, one THF and two chloride donors.
\end{abstract}

\section{Introduction}

Cyclopentadienyl based organolanthanide complexes have been used as catalysts for a wide range of processes, including hydrogenations, polymerisations and $\mathrm{H}-\mathrm{X}$ transformations such as hydrosilation. ${ }^{1}$ Group 3 and lanthanide metals have also been used with a range of ligands to catalyse a variety of polymerisation processes. ${ }^{2}$ In an attempt to extend and control this reactivity, recent research efforts have been directed towards substitution of the cyclopentadienyl ligands in the metallocene set-up by other anionic ligand systems. ${ }^{3}$ Careful ligand design is mainly a question of providing the right steric environment about the metal center. Ideally, a ligand system must provide enough steric bulk to prevent solvent ligation, complex dimerisation and ligand redistribution, but not so much as to shut down the catalytic reactivity. Solvent ligation is particularly troublesome in the synthesis of polymerisation catalysts as the solvent prevents monomer coordination, which is a crucial step in many metal catalysed polymerisations.

The lanthanides and group three metals have hard $\mathrm{M}^{3+}$ ions so are well suited to dianionic chelating nitrogen and oxygen containing ligands such as those shown in Fig. 1. The design of these ligands allows flexibility in the type of nitrogen donor; amine, imine and pyridyl, and also in steric demand, especially the substituents on the aryl rings. Due to the lanthanide contraction the size of the metal ions decreases across the period. Although the change in size is small between consecutive lanthanide ions, ${ }^{4}$ it can cause substantial differences in reactivity. ${ }^{5-9}$ Therefore, the additional variable of ion size should be considered when designing libraries of lanthanide complexes. In addition to this, the paramagnetic nature of many of the $\mathrm{Ln}^{3+}$ ions renders them unsuitable for NMR studies and, therefore, they have been studied to a lesser extent than their diamagnetic counterparts in catalysis.

There is a growing interest in the controlled polymerisation of cyclic esters as these yield biodegradable, biocompatible polymers. ${ }^{10}$ Polycaprolactone has been used in biomedicine as surgical sutures and as a delivery medium for the controlled release of drugs. Various species including metal alkoxide complexes and metal alkyls such as alkyl aluminium, alkyl tin and alkyl lanthanides have been used as initiators for the ring opening polymerisation of
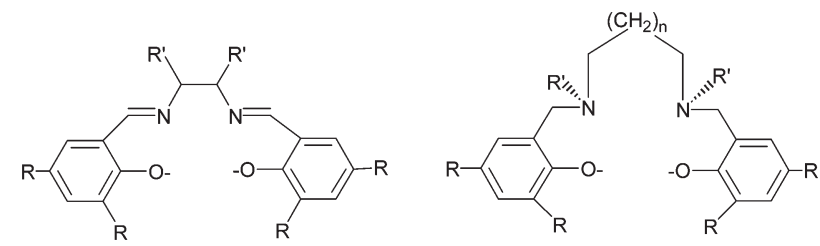<smiles>[R]c1cc([R])c(O)c(CN(Cc2ccccn2)Cc2cc([R])cc([R])c2O)c1</smiles>

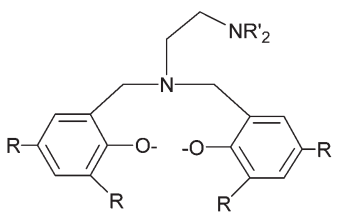

A Y $\left(\mathrm{N}\left\{\mathrm{SiMe}_{3}\right\}_{2}\right)_{3}, \mathrm{~B} \mathrm{Y}\left(\mathrm{N}\left\{\mathrm{SiMe}_{2} \mathrm{H}\right\}_{2}\right)_{3} .2 \mathrm{THF}, \mathrm{C} \mathrm{La}\left(\mathrm{N}\left\{\mathrm{SiMe}_{3}\right\}_{2}\right)_{3}$ $\mathrm{D} \mathrm{La}\left(\mathrm{N}\left\{\mathrm{SiMe}_{2} \mathrm{H}\right\}_{2}\right)_{3}$. 2THF, E Pr(N\{SiMe$\left.\}_{2}\right)_{3}, \mathrm{~F} \mathrm{Sm}\left(\mathrm{N}\left\{\mathrm{SiMe}_{3}\right\}_{2}\right)_{3}$ $\mathrm{G} \mathrm{Gd}\left(\mathrm{N}\left\{\mathrm{SiMe}_{3}\right\}_{2}\right)_{3}, \mathrm{H} \mathrm{Yb}\left(\mathrm{N}\left\{\mathrm{SiMe}_{3}\right\}_{2}\right)_{3}$

$$
R, R^{\prime}=H, a l k y l
$$

Fig. 1 Tetradentate amine-phenoxide, imine-phenoxide (Schiff-base) ligands and group 3/lanthanide amide reagents used to prepare complexes.

$\varepsilon$-caprolactone. ${ }^{8,10-46}$ Only some of these complexes, however, are able to initiate the polymerisation in a living fashion. Broadening of the molecular weight distribution is frequently a result of competing transesterification reactions or rapid backbiting degradation of the growing polycaprolactone chains that results in ring-chain equilibrium systems. ${ }^{37}$ Initiators closely related to those reported here have been reported during the course of this work. ${ }^{23,47-49}$

Although in their infancy, high-throughput methods are finding increasing use in the discovery of new transition metal based catalysts..$^{50-52}$ In particular, high-throughput methods have recently been used to discover a range of olefin polymerisation catalysts. ${ }^{53-57}$ While these methods have been used in the evaluation of lanthanide catalysts, ${ }^{58}$ their use has not flourished in contrast to their utility in organotransition metal chemistry. This may be due to the perception that lanthanide based catalysts are less robust and more reactive than their transition metal counterparts. 
We report here new initiators for controlled ring-opening polymerisation of caprolactone using lanthanides supported by $[\mathrm{ONNO}]^{2-}$ ancillary ligands. We have used simple synthetic and screening methods that could be applied to other lanthanide polymerisation catalysts/initiators.

\section{Experimental}

\section{General considerations}

All manipulations were performed under an atmosphere of dry oxygen-free nitrogen or argon by means of standard Schlenk or glovebox techniques. Analytical grade hexane and THF were purchased from Fisher and dried by passage through a tower of silica and degassed by passage through a tower of Q- 5 catalyst under positive pressure of nitrogen. Anhydrous diethyl ether and toluene were distilled from sodium benzophenone ketyl under argon. Deuterated benzene and toluene were dried by refluxing with molten sodium or potassium metal and deuterated chloroform was dried over $\mathrm{CaH}_{2}$. The deuterated solvents were then trap-to-trap distilled, and freeze-pump-thaw degassed three times. $\mathrm{YCl}_{3} \cdot 6 \mathrm{H}_{2} \mathrm{O}, \mathrm{LaCl}_{3} \cdot 6 \mathrm{H}_{2} \mathrm{O}$, $\mathrm{PrCl}_{3} \cdot 6 \mathrm{H}_{2} \mathrm{O}, \mathrm{SmCl}_{3} \cdot 6 \mathrm{H}_{2} \mathrm{O}, \mathrm{GdCl}_{3} \cdot 6 \mathrm{H}_{2} \mathrm{O}$, and $\mathrm{YbCl}_{3} \cdot 6 \mathrm{H}_{2} \mathrm{O}$ were purchased from Strem and used as received. $\mathrm{YCl}_{3}(\mathrm{THF})_{3.5}, \mathrm{LaCl}_{3}(\mathrm{THF})_{4}$, $\mathrm{PrCl}_{3}(\mathrm{THF})_{4}, \mathrm{SmCl}_{3}(\mathrm{THF})_{3.5}, \mathrm{GdCl}_{3}(\mathrm{THF})_{3.5}, \mathrm{YbCl}_{3}(\mathrm{THF})_{3}$ and lanthanide amide complexes were synthesised according to a literature procedure. ${ }^{60,9,61}$ All organic materials were purchased from Aldrich or Lancaster. $\mathrm{LiN}\left(\mathrm{SiMe}_{3}\right)_{2}$ and $\mathrm{LiN}\left(\mathrm{SiMe}_{2} \mathrm{H}\right)_{2}$ were prepared from their corresponding secondary amines by reaction with BuLi in dry diethyl ether. Caprolactone was dried over molecular sieves and freeze-pump-thaw degassed three times prior to use. Ligands were stored in a desiccator over anhydrous $\mathrm{CaCl}_{2}$ prior to use.

\section{Characterisation}

NMR spectra were recorded on a Jeol EX 270 instrument, a Bruker AMX-300 instrument or a Bruker AMX-500 instrument. ${ }^{1} \mathrm{H}$ NMR spectra were referenced to residual protons in the deuterated solvent and ${ }^{13} \mathrm{C}$ NMR spectra to the ${ }^{13} \mathrm{C}$ atoms therein. Elemental analyses were performed by Elemental Microanalysis Ltd., Devon. Mass spectra were recorded on a Fisons Instruments VG Analytical Autospec Mass Spectrometer. GPC analyses were performed by Rapra Technology Ltd., Shrewsbury, UK. The GPC system was calibrated with narrow distribution polystyrene calibrants obtained from Polymer Laboratories Ltd. The results are therefore expressed as for polystyrene and are summarised as the calculated molecular weight averages and polydispersity. GPC samples were prepared by adding $10 \mathrm{ml}$ of chloroform to $20 \mathrm{mg}$ of samples. The samples were then left to stand for at least $4 \mathrm{~h}$ to dissolve. The solutions were mixed thoroughly and filtered through a 0.2 micron polyamide membrane into sample vials, which were placed in an autosampler. PLgel guard plus $2 \times$ mixed bed-B $(30 \mathrm{~cm}, 10$ microns $)$ columns were used at a nominal flow-rate of $1.0 \mathrm{~mL} \mathrm{~min}{ }^{-1}$. Analyses were made at $30^{\circ} \mathrm{C}$ using a refractive index detector.

\section{Ligand syntheses}

A range of tetradentate nitrogen and oxygen donor ligands, $\mathbf{L}_{1-21}$, were prepared using previously reported procedures, ${ }^{59,62}$ on a $2.5 \mathrm{mmol}$ scale in a carousel reactor (Radleys, UK), Tables 1 and 2. The resulting white solids were isolated in $68-83 \%$ yield and were characterised by ${ }^{1} \mathrm{H}$ NMR spectroscopy. In addition to this, selected ligands were also characterised by ${ }^{13} \mathrm{C}\left\{{ }^{1} \mathrm{H}\right\}$ NMR spectroscopy and CI mass spectrometry. Crystals of $\mathbf{L}_{12}$ (1) suitable for X-ray diffraction analysis were grown by slow cooling of a hot methanol solution. Representative data, $\mathbf{L}_{12}$, m.p. $89{ }^{\circ} \mathrm{C}$ (from $\mathrm{MeOH}$ ): Found: C, 78.2; $\mathrm{H}, 11.3 ; \mathrm{N}, 4.9, \mathrm{C}_{38} \mathrm{H}_{64} \mathrm{~N}_{2} \mathrm{O}_{2}$ requires $\mathrm{C}, 78.6 ; \mathrm{H}, 11.1 ; \mathrm{N}$, 4.8\%: $\delta_{\mathrm{H}}\left(\mathrm{CDCl}_{3}\right) 10.55(2 \mathrm{H}, \mathrm{s}, \mathrm{OH}), 7.04\left(2 \mathrm{H}, \mathrm{d}, J_{\mathrm{HH}}=2.2 \mathrm{~Hz}, \mathrm{CH}\right)$, $6.71\left(2 \mathrm{H}, \mathrm{d}, J_{\mathrm{HH}}=2.2 \mathrm{~Hz}, \mathrm{CH}\right), 3.62\left(4 \mathrm{H}, \mathrm{s}, \mathrm{C}-\mathrm{CH}_{2}-\mathrm{N}\right), 2.58(4 \mathrm{H}$, $\left.\mathrm{s}, \mathrm{N}-\mathrm{C}_{2} \mathrm{H}_{4}-\mathrm{N}\right), 2.18,2.15,\left(6 \mathrm{H}, 1\right.$ br s and $\left.1 \mathrm{~s}, \mathrm{NCH}_{3}\right), 1.84(4 \mathrm{H}, \mathrm{q}$, $\left.J_{\mathrm{HH}}=7 \mathrm{~Hz}, 2 \mathrm{CCH}_{2} \mathrm{CH}_{3}\right), 1.54\left(4 \mathrm{H}, \mathrm{q}, J_{\mathrm{HH}}=7 \mathrm{~Hz}, 2 \mathrm{CCH}_{2} \mathrm{CH}_{3}\right)$, $1.32\left(12 \mathrm{H}, \mathrm{s}, 2 \mathrm{C}\left(\mathrm{CH}_{3}\right)_{2}\right), 1.21\left(12 \mathrm{H}, \mathrm{s}, 2 \mathrm{C}\left(\mathrm{CH}_{3}\right)_{2}\right), 0.60(12 \mathrm{H}, \mathrm{q}$, $\left.J_{\mathrm{HH}}=7 \mathrm{~Hz}, 4 \mathrm{CH}_{2} \mathrm{CH}_{3}\right): \delta_{\mathrm{C}}\left(\mathrm{CDCl}_{3}\right) 153.9(\mathrm{CH}), 138.6(\mathrm{CH}), 133.8$
$(\mathrm{CH}), 125.1(\mathrm{CH}), 124.0(\mathrm{CH}), 120.8(\mathrm{CH}), 62.7\left(\mathrm{CH}_{2}\right), 53.6\left(\mathrm{CH}_{2}\right)$, $41.5\left(\mathrm{NCH}_{3}\right), 38.4\left(\mathrm{CH}_{2}\right), 37.2\left(\mathrm{CH}_{2}\right), 32.8(\mathrm{C}), 28.6\left(\mathrm{CH}_{3}\right), 27.6$ $\left(\mathrm{CH}_{3}\right), 9.6\left(\mathrm{CH}_{3}\right), 9.1\left(\mathrm{CH}_{3}\right): \mathrm{MS}(+\mathrm{CI})(\mathrm{m} / \mathrm{z}): 581[\mathrm{M}+\mathrm{H}]^{-}, 335$ $\left[\mathrm{M}-\mathrm{CH}_{2} \mathrm{ArOH}\right]^{-}, 247\left[\mathrm{CH}_{2} \mathrm{ArOH}\right]^{-}, 217[\mathrm{Ar}]^{-}$.

\section{Typical metal complexation procedure}

$4.2 \mathrm{mmol}$ of ligand was weighed into a Schlenk flask and $30 \mathrm{~mL}$ dry hexane added. A hexane solution $(30 \mathrm{~mL})$ containing $4.2 \mathrm{mmol}$ $\mathrm{Ln}\left[\mathrm{N}\left(\mathrm{SiMe}_{3}\right)_{2}\right]_{3}$ was added to this suspension at $-78^{\circ} \mathrm{C}$. This was stirred at room temperature overnight. The solvent was removed under vacuum and the resulting solid washed with pentane at $0{ }^{\circ} \mathrm{C}$. Solids were isolated as follows; $\operatorname{Pr}_{2}\left[\mathrm{~N}\left\{\mathrm{SiMe}_{3}\right\}_{2}\right](2.23 \mathrm{~g}, 81 \%)$, $\mathrm{YL}_{2}\left[\mathrm{~N}\left\{\mathrm{SiMe}_{3}\right\}_{2}\right](1.82 \mathrm{~g}, 72 \%), \mathrm{LaL}_{9}\left[\mathrm{~N}\left\{\mathrm{SiMe}_{3}\right\}_{2}\right](2.36 \mathrm{~g}, 64 \%)$, $\mathrm{YL}_{9}\left[\mathrm{~N}\left\{\mathrm{SiMe}_{3}\right\}_{2}\right](2.78 \mathrm{~g}, 80 \%), \operatorname{PrL}_{9}\left[\mathrm{~N}\left\{\mathrm{SiMe}_{3}\right\}_{2}\right](3.36 \mathrm{~g}, 91 \%)$, $\mathrm{GdL}_{9}\left[\mathrm{~N}\left\{\mathrm{SiMe}_{3}\right\}_{2}\right](2.22 \mathrm{~g}, 59 \%), \mathrm{YbL} 9\left[\mathrm{~N}\left\{\mathrm{SiMe}_{3}\right\}_{2}\right](3.37 \mathrm{~g}, 88 \%)$.

Sample NMR data, $\mathrm{YL}_{2}\left[\mathrm{~N}\left\{\mathrm{SiMe}_{3}\right\}_{2}\right] ; \delta_{\mathrm{H}}\left(295 \mathrm{~K}, 300 \mathrm{MHz}, \mathrm{C}_{7} \mathrm{D}_{8}\right)$ 6.91 (s, 2H, Ar), 6.73 (s, 2H, Ar), 3.37 (br, 4H, CH $\mathrm{CH}_{2}$ ), 2.32 (br, 6H, $\left.\mathrm{CH}_{3} \mathrm{Ar}\right), 2.28$ (br, 6H, $\left.\mathrm{CH}_{3} \mathrm{Ar}\right), 2.24,2.19\left(2 \times\right.$ br s, $\left.6 \mathrm{H}, \mathrm{N}\left(\mathrm{CH}_{3}\right)_{2}\right)$, 1.27 (br s, $\left.4 \mathrm{H}, \mathrm{CH}_{2} \mathrm{CH}_{2} \mathrm{NMe}_{2}\right), 0.36,0.31\left(2 \times\right.$ br s, $\left.18 \mathrm{H}, \mathrm{Si}\left(\mathrm{CH}_{3}\right)_{3}\right)$; $\delta_{\mathrm{H}}\left(215 \mathrm{~K}, 300 \mathrm{MHz}, \mathrm{C}_{7} \mathrm{D}_{8}\right) 6.93$ (s, 2H, Ar), 6.80 (s, 2H, Ar), 3.42 (br s, 2H, $\mathrm{CH}_{2} \mathrm{Ar}$ ), 2.91 (br s, $2 \mathrm{H}, \mathrm{CH}_{2} \mathrm{Ar}$ ), 2.46-2.23 (m, 12H, $\mathrm{CH}_{3} \mathrm{Ar}$ ), 2.13 (br s, 6H, N( $\left.\mathrm{CH}_{3}\right)_{2}$ ), 1.57 (br s, $2 \mathrm{H}, \mathrm{CH}_{2} \mathrm{CH}_{2} \mathrm{NMe}_{2}$ ), 1.17 (br s, $2 \mathrm{H}, \mathrm{CH}_{2} \mathrm{CH}_{2} \mathrm{NMe}_{2}$ ), 0.44 (br s, $18 \mathrm{H}, \mathrm{Si}\left(\mathrm{CH}_{3}\right)_{3}$ ).

\section{High-throughput procedure for metal complexation}

Initiators were prepared in a carousel reactor (Radleys) using similar methods to those described above. The reaction vessels containing the ligands and stir bars were taken into the glove box and lanthanide amide, Fig. $1 \mathrm{~A}-\mathrm{H}$, added to each. Dry hexane was cooled to $0{ }^{\circ} \mathrm{C}$ and added under nitrogen via cannula to each carousel tube. After stirring overnight, the solvent was removed under vacuum and to each solid was added a known amount of dry toluene to give a stock initiator solution. Reactions were assumed to yield the lanthanide complexes cleanly in $100 \%$ yield when calculating quantities of initiator used in polymerisation screenings, even though test reactions afforded yields of only $59-91 \%$.

\section{Polymerisation}

Polymerisation reactions were carried out in a 24-vessel carousel reactor (Radleys) in a glove box. $0.0118 \mathrm{mmol}$ of the appropriate initiator (from the stock solution) was added to each reaction vessel with a further $2 \mathrm{~mL}$ dry toluene. While stirring, $1.18 \mathrm{mmol}$ (100 mol\%) $\varepsilon$-caprolactone was added to each vessel. After $1 \mathrm{~h}$, the reactions were quenched. Solvents were removed under vacuum. All residues were analysed using ${ }^{1} \mathrm{H}$ NMR spectroscopy. Analysis of solids was carried out using gel permeation chromatography. $\varepsilon$-Caprolactone, $\delta_{\mathrm{H}}\left(\mathrm{C}_{7} \mathrm{D}_{8}\right) 3.40\left(2 \mathrm{H}, \mathrm{t}, J_{\mathrm{HH}}=4.3 \mathrm{~Hz}, \mathrm{OCH}_{2} \mathrm{CH}_{2}\right), 2.28$ $\left(2 \mathrm{H}, \mathrm{t}, \mathrm{O}_{2} \mathrm{CCH}_{2} \mathrm{CH}_{2}\right), 1.35$ (m, 6H, $\mathrm{CH}_{2} \mathrm{CH}_{2} \mathrm{CH}_{2}$ ): Polycaprolactone, $\delta 3.97\left(2 \mathrm{H}, \mathrm{t}, J_{\mathrm{HH}}=6.9 \mathrm{~Hz}, \mathrm{OCH}_{2} \mathrm{CH}_{2}\right), 2.01\left(2 \mathrm{H}, \mathrm{t}, \mathrm{O}_{2} \mathrm{CCH}_{2} \mathrm{CH}_{2}\right)$, $1.47\left(4 \mathrm{H}, \mathrm{m}, \mathrm{CH}_{2} \mathrm{CH}_{2} \mathrm{CH}_{2}\right), 1.18\left(\mathrm{~m}, 2 \mathrm{H}, \mathrm{CH}_{2} \mathrm{CH}_{2} \mathrm{CH}_{2}\right)$.

Attempted 'activation' with benzyl alcohol. In a glove box, initiators which did not yield polymer initially (e.g. those utilising $\mathbf{L}_{17}-\mathbf{L}_{21}$ ) were added to carousel tubes. Using a micro-syringe, distilled, degassed benzyl alcohol $(2 \mu \mathrm{L})$, was added to each carousel tube, followed by caprolactone. The mixtures were stirred at room temperature for $4 \mathrm{~h}$ then the solvent was removed under vacuum. ${ }^{1} \mathrm{H}$ NMR spectra of the residues indicated that no polymer had formed.

Block copolymerisation. To a solution of $\mathrm{GdL}_{9}\left[\mathrm{~N}\left(\mathrm{SiMe}_{3}\right)_{2}\right]$ $(0.09 \mathrm{~g}, 0.1 \mathrm{mmol})$ in $2 \mathrm{~mL}$ toluene was added $\varepsilon$-caprolactone $(0.23 \mathrm{~g}, 2.0 \mathrm{mmol})$. The mixture was stirred for $1 \mathrm{~h}$ and an aliquot removed for ${ }^{1} \mathrm{H}$ NMR analysis. $100 \%$ monomer consumption was evident. An additional $2 \mathrm{~mL}$ toluene was added to the gelatinous mixture, followed by $\delta$-valerolactone $(0.20 \mathrm{~g}, 2.0 \mathrm{mmol})$. After an additional $1 \mathrm{~h}$ stirring, an aliquot was removed for ${ }^{1} \mathrm{H}$ NMR analysis. Again, 100\% monomer consumption was evident. The solvent was removed under vacuum to give a colorless solid, poly $(\varepsilon-$ caprolactone- $c o-\delta$-valerolactone), with a film-like appearance. 
Table 1 Library of tetradentate amine-phenoxide ligands

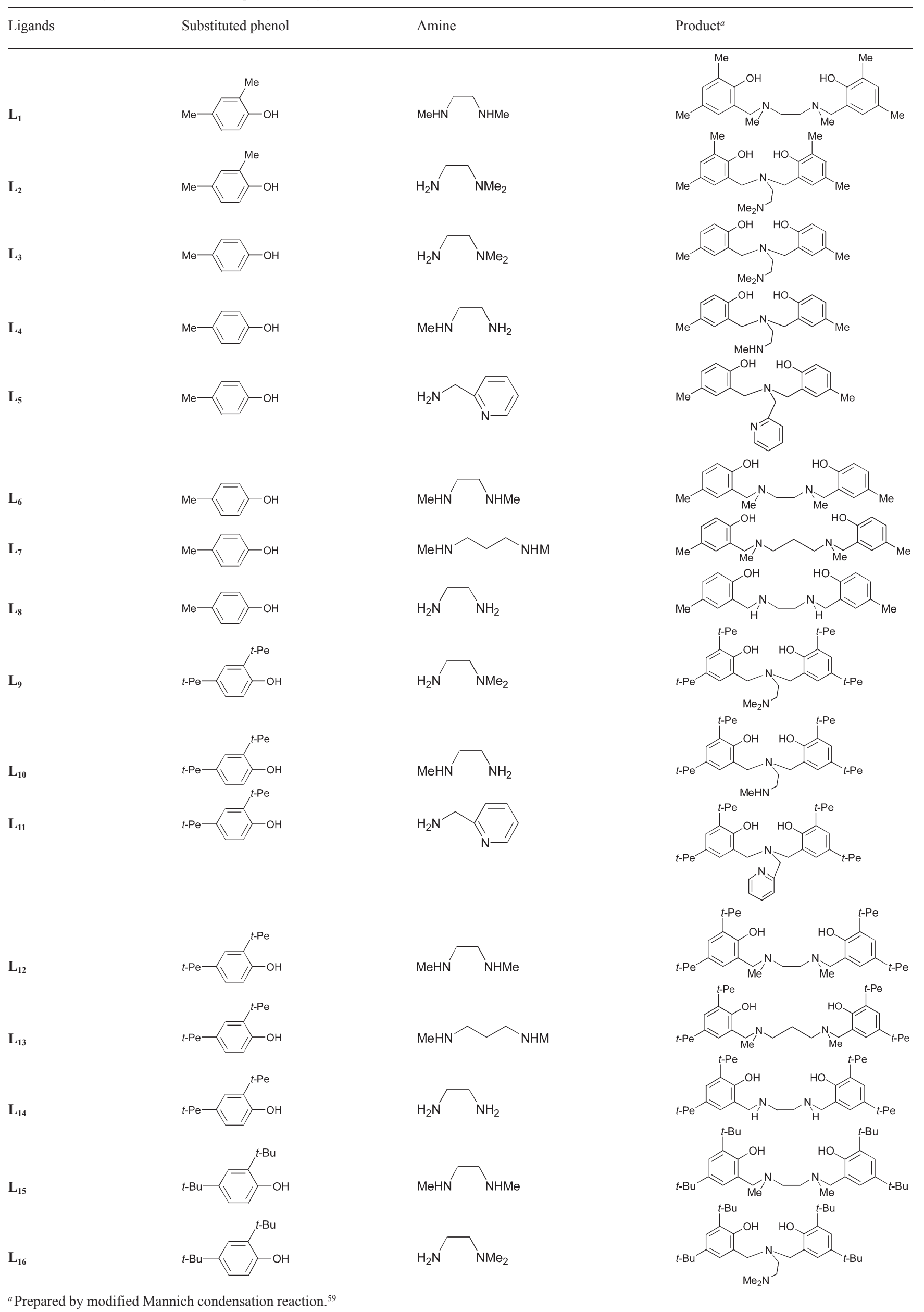


Table 2 Library of tetradentate imine-phenoxide (Schiff-base) ligands



${ }^{a}$ Prepared via Schiff base condensation reaction. ${ }^{62}$

\section{X-ray crystallography}

Single crystals of $\mathbf{1}$ suitable for X-ray diffraction were grown from a saturated methanol solution, while $\mathbf{2}$ were obtained from slow evaporation of a toluene solution in a glove box. Diffraction data were collected at $110 \mathrm{~K}$ and $115 \mathrm{~K}$, respectively, on a Bruker Smart Apex diffractometer with $\mathrm{Mo}-\mathrm{K}_{\alpha}$ radiation $(\lambda=0.71073 \AA)$ using a SMART CCD camera. Diffractometer control, data collection and initial unit cell determination was performed using SMART. ${ }^{63}$ Frame integration and unit-cell refinement software was carried out with SAINT+. ${ }^{64}$ Absorption corrections were applied by SADABS. ${ }^{65}$ Structures were solved by direct methods (SHELXS$97)^{66}$ and refined by full-matrix least squares based on $|F|^{2}$ using SHELXL-97.67 All non-hydrogen atoms were refined anisotropically. Hydrogen atoms were placed using a "riding model" and included in the refinement at calculated positions. In $\mathbf{2}$, there is significant disorder in the position of one of the tert-pentyl groups (C28-C32). This could not be resolved using two possible positions for the ethyl terminal carbon and two rotations of the two methyl and $\mathrm{CH}_{2}$ groups. Therefore, this tert-pentyl group is modelled in a single position with the methyl groups isotropic. There is also a disordered toluene of crystallization modelled as the superposition of two orientations.

CCDC reference numbers 238099 and 238100.

See http://www.rsc.org/suppdata/dt/b4/b406841f/ for crystallographic data in CIF or other electronic format.

\section{Results and discussion}

\section{Initiator libraries}

Ligands were prepared in a parallel fashion to give a library of ligands on a $2.5 \mathrm{mmol}$ scale from readily available starting materials via simple condensation reactions. The substituents on the phenol were varied in order to examine the effects of bulkier (e.g. tert-
Table 3 Details of crystallographic data and refinements for $\mathbf{1}$ and $\mathbf{2}$

\begin{tabular}{lll}
\hline & $\mathbf{1}$ & $\mathbf{2}$ \\
\hline Chemical formula & $\mathrm{C}_{38} \mathrm{H}_{64} \mathrm{~N}_{2} \mathrm{O}_{2}$ & $\mathrm{C}_{84} \mathrm{H}_{140} \mathrm{Cl}_{2} \mathrm{Gd}_{2} \mathrm{~N}_{4} \mathrm{O}_{6}\left(\mathrm{C}_{7} \mathrm{H}_{8}\right)$ \\
Formula weight & 580.91 & 1779.53 \\
$T / \mathrm{K}$ & $110(2)$ & $115(2)$ \\
Crystal system & Orthorhombic & Monoclinic \\
Space group & $P b c a$ & $C 2 / c$ \\
$a / \AA$ & $17.3502(14)$ & $28.077(4)$ \\
$b / \AA$ & $11.9417(9)$ & $17.091(3)$ \\
$c / \AA$ & $35.435(3)$ & $18.815(3)$ \\
$\alpha /{ }^{\circ}$ & 90 & 90 \\
$\beta /{ }^{\circ}$ & 90 & $91.758(3)$ \\
$\gamma /{ }^{\circ}$ & 90 & 90 \\
$V / \AA^{3}$ & $7341.8(10)$ & $9025(2)$ \\
$Z$ & 8 & 4 \\
$D_{c} / \mathrm{Mg}$ m $^{-3}$ & 1.051 & 1.310 \\
$\mu /$ mm $^{-1}$ & 0.063 & 1.568 \\
$F(000)$ & 2576 & 3728 \\
$\theta$ Range for collection $/{ }^{\circ}$ & $1.15-25.08$ & $1.39-25.05$ \\
No. of reflns. colld. & 39720 & 24717 \\
No. of indep. reflns. & 6503 & 7957 \\
$R($ int $)$ & 0.0598 & 0.0808 \\
$R[I>2 \sigma(I)]$ & 0.0423 & 0.0595 \\
$w R$ & 0.1013 & 0.1559 \\
GOF on $F^{2}$ & 0.992 & 1.047 \\
& & \\
\hline & &
\end{tabular}

pentyl, tert-butyl) and less bulky (e.g. methyl, hydrogen) groups. The type of nitrogen donor was varied (secondary amine, tertiary amine, imine and pyridine) and the structure of the ligand was changed by adjusting the chain length between the nitrogens. Ligands were isolated as white or yellow solids. The novel tert-pentyl substituted ligand $\mathbf{L}_{\mathbf{1 2}}$ (1) was crystallised from a saturated methanol solution. The molecular structure, Fig. 2, shows no intermolecular $\mathrm{H}$-bonding and the bond lengths and angles about each atom are unexceptional. 
Table 4 Screening of library 1 for activity

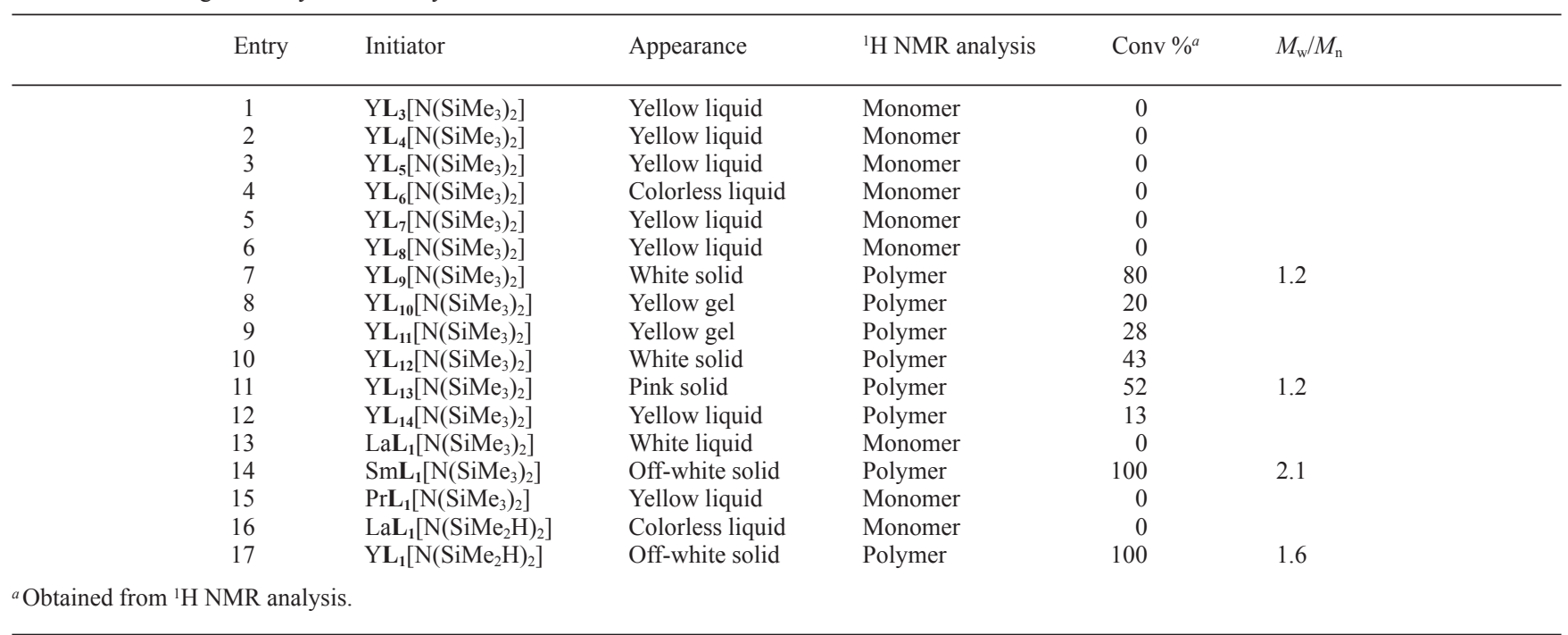

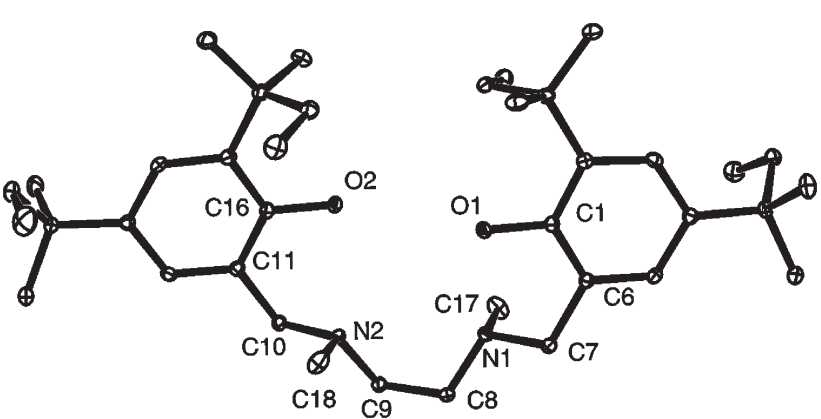

Fig. 2 Molecular structure of 1. H atoms omitted for clarity. Thermal ellipsoids are drawn at the $20 \%$ probability level. Selected bond lengths $(\AA)$ and angles $\left({ }^{\circ}\right)$ : C1-O1 1.376(2), C16-O2 1.374(2), C7-N1 1.472(2), C8-N1 1.460(2), C9-N2 1.464(2), C10-N2 1.473(2), C7-N1-C8 110.44(12), C9-N2-C10 109.79(13).

Several routes are available for the synthesis of lanthanide complexes, including transamination, alkane elimination and salt metathesis. ${ }^{1}$ Routes used for in situ catalyst screening should be clean, high yielding and involve the minimum amount of work up. The advantages of transamination over the traditional salt metathesis route include reactions in non-coordinating solvents, easy product purification and near quantitative yields. Due to the steric bulk of the bis(trimethylsilyl)amido ligand incomplete ligand exchange reactions with other bulky ligands may occur. The extended silylamide route offers a suitable alternative,, 96 albeit at a greater financial cost.

To test the transamination reaction, Scheme 1 , as a potential route to the desired lanthanide complexes, the reaction of $\left[\mathrm{Y}\left(\mathrm{N}\left\{\mathrm{SiMe}_{3}\right\}_{2}\right)_{3}\right]$ with protonated ligands was performed in a Schlenk flask. After removal of solvent the product was washed with cold pentane. ${ }^{1} \mathrm{H}$ NMR analysis of the product exhibited no resonances characteristic of $\left[\mathrm{Y}\left(\mathrm{N}\left\{\mathrm{SiMe}_{3}\right\}_{2}\right)_{3}\right]$ and the high frequency resonance, between 9.5 and $14.0 \mathrm{ppm}$, indicative of the phenolic protons in the ligand was also absent. The chemical shifts of the ligand and remaining $\mathrm{N}\left(\mathrm{SiMe}_{3}\right)_{2}$ group indicated complex formation. $\mathrm{YL}_{2} \mathrm{~N}\left(\mathrm{SiMe}_{3}\right)_{2}$ was studied using variable temperature NMR and showed that the resulting complex is fluxional and may display geometric isomerisation. At $215 \mathrm{~K}$, the pendant amine is bound to the metal center and two different $\mathrm{CH}_{2}$ environments can be seen for this arm of the ligand. However, coupling constants were unobtainable, possibly due to rapid ring inversion of the chelate ring, and the solution structure of the complex remains uncertain. Recently, transamination reactions have been successfully employed by Carpentier and co-workers to prepare a series of monomeric lanthanum and yttrium complexes of relevance to this work. ${ }^{23,48}$

Transamination was therefore applied in the preparation of the first library of initiators, Table 4 . A carousel reactor was used to

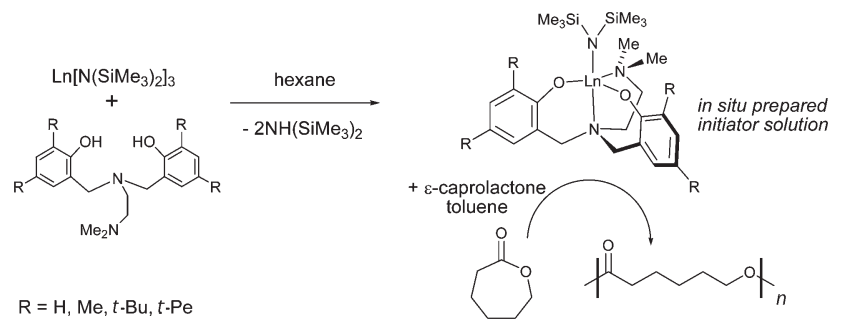

Scheme 1

prepare up to twelve complexes simultaneously. Metal tris-amides were added in the glove box to the reaction vessels containing the ligands, Scheme 1. After removal of the solvent the products were not washed, as this was deemed unnecessary for initial screening of the complexes. They were stored in toluene in the glove box until required.

It is essential that the lanthanide tris-amide reagents are isolated and are not made in situ, as the residual lithium chloride undergoes further metathesis reactions with the aminophenoxide metal complexes to give chloride containing species. Crystals from such a reaction mixture were grown by slow evaporation of a toluene solution in a glove box. A single crystal X-ray analysis of $\mathbf{2}$ showed it to be a centrosymmetric dimeric complex, Fig. 3 and Fig. 4. The geometry at each gadolinium center is best described as distorted capped trigonal prismatic. The gadolinium coordination distances are unexceptional. These complexes are inactive in the polymerisation of caprolactone on the timescale used. $\dagger$

\section{Polymerisation screening}

The polymerisation reactions were carried out in a 24-vessel carousel reactor in a glove box under a nitrogen atmosphere. Each initiator was dissolved in toluene and stirred with 100 equiv. of $\varepsilon$ caprolactone. After $1 \mathrm{~h}$ the reactions were quenched and the solvent removed under vacuum. The resulting products were screened by their appearance and ${ }^{1} \mathrm{H}$ NMR spectroscopy. It was assumed that if the tubes contained a solid that a polymer had formed and if it remained as a liquid only starting monomer was present. Control reactions were also performed using protonated ligand, lanthanide tris-amides, hexamethyldisilazane, $\mathrm{Li}\left[\mathrm{N}\left(\mathrm{SiMe}_{3}\right)_{2}\right]$ and $\mathrm{LnCl}_{3}(\mathrm{THF})_{n}$. These confirmed that any reagents used in the syntheses of our complexes were themselves inactive in the polymerisation. In addition to these negative control reactions, a positive control reaction using anhydrous $\mathrm{HCl}$ in diethyl ether $(1.0 \mathrm{M})$ was employed. This gave a polydisperse high molecular weight polymer product. Reactions were duplicated to ascertain the effect of any adventitious water. As

$\dagger\left[\mathrm{YL}_{\mathbf{9}}(\mu-\mathrm{Cl})\right]_{2}$ polymerizes 100 equivalents of $\varepsilon$-caprolactone over $48 \mathrm{~h}$. There is no evidence for polymerization after $1 \mathrm{~h}$. 


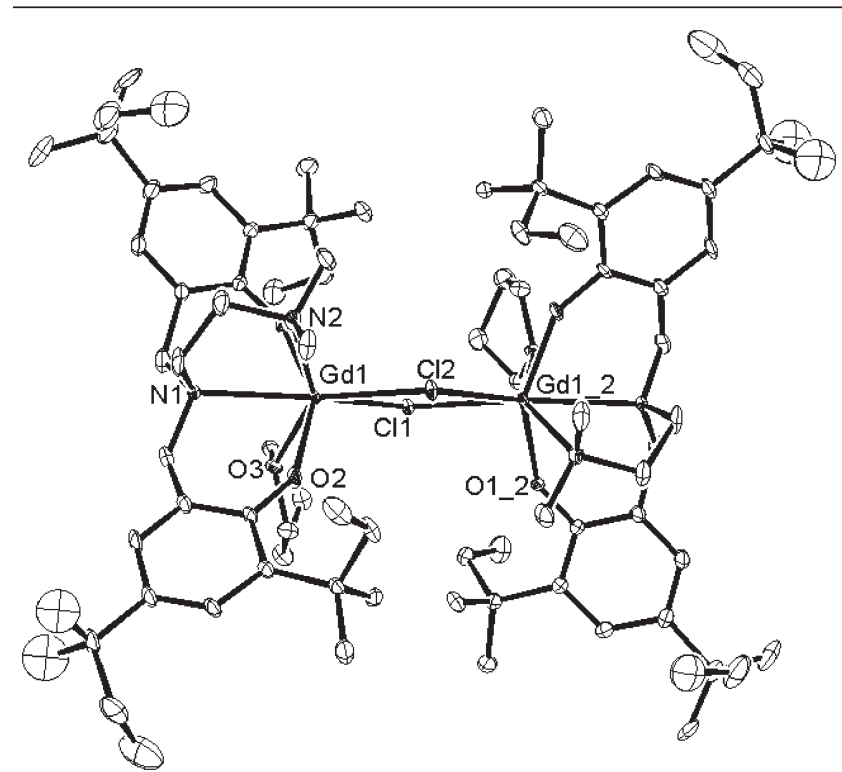

Fig. 3 Molecular structure of 2. Solvent of crystallisation and $\mathrm{H}$ atoms omitted for clarity. Thermal ellipsoids are drawn at the $20 \%$ probability level.



Fig. 4 Structural environment about the dinuclear Gd core of 2 . Selected bond lengths $(\AA)$ and angles $\left({ }^{\circ}\right)$ : Gd1-Cl1 2.8037(15), Gd1-Cl2 2.7948(16), Gd1-O1 2.188(5), Gd1-O2 2.147(6), Gd1-O3 2.467(5), Gd1-N1 2.605(6), Gd1-N2 2.607(6), Gd1-Cl1-Gd1_2 108.16(8), Gd1-Cl2-Gd1_2 108.67(9), Cl1-Gd1-Cl2 71.59(6), Cl1-Gd1-O3 75.16(13), C11-Gd1-O2 118.91(14), C11-Gd1-N2 133.98(15), O2-Gd1-O3 81.6(2), O2-Gd1-N1 74.60(18), N1-Gd1-O1 76.13(18), N1-Gd1-N2 70.42(19), O1-Gd1-O2 149.50(19), N2-Gd-O3 148.67(18).

with many lanthanide catalysts/initiators, precautions must be taken to prevent contamination with water, which significantly inhibits reactivity.

The contents of all tubes were analysed by ${ }^{1} \mathrm{H}$ NMR spectroscopy. Many papers have been published which discuss the NMR spectra of polycaprolactone and its co-polymers. ${ }^{33}$ The monomer and polymer have different spectra, the polymer $\mathrm{CH}_{2}-\mathrm{O}$ protons are $0.5 \mathrm{ppm}$ higher in frequency than in the monomer. In addition to this, their coupling constants $J_{\mathrm{HH}} \sim 7 \mathrm{~Hz}$ in the polymer and $J_{\mathrm{HH}} \sim 4 \mathrm{~Hz}$ in the monomer provide further confirmation of polymerisation activity. In some cases, it appeared as if no polymer had formed, however, a small amount of polymer had formed and was dissolved in the residual monomer. Therefore, ${ }^{1} \mathrm{H}$ NMR data provides a more accurate screen for these processes than visual inspection of the reaction tubes for solid polymer residues.

\section{Inferences from initial screening}

Upon removal of the solvent, a gel or solid was observed for seven out of the seventeen combinations in library 1 (Table 4). This library varied the amine-phenoxide ligand and its steric demand whilst keeping the metal reagent, $\mathrm{Y}\left(\mathrm{N}\left\{\mathrm{SiMe}_{3}\right\}_{2}\right)_{3}$, constant, entries 1-12. It also varied the metal center whilst keeping the ligand, $\mathbf{L}_{1}$, constant, entries 13-17. It became apparent that this type of initiator is only active when the phenoxides are di-substituted with alkyl groups as shown in Scheme 1. If there is no substituent in the 2-position of
Table 5 Inactive species generated in libraries 2 and 3

Library 2

$\begin{array}{ll}\mathrm{YbL}_{17}\left[\mathrm{~N}\left(\mathrm{SiMe}_{3}\right)_{2}\right] & \operatorname{Pr}_{17}\left[\mathrm{~N}\left(\mathrm{SiMe}_{3}\right)_{2}\right] \\ \mathrm{YL}_{17}\left[\mathrm{~N}\left(\mathrm{SiMe}_{3}\right)_{2}\right] & \mathrm{LaL}_{\mathbf{1 7}}\left[\mathrm{N}\left(\mathrm{SiMe}_{3}\right)_{2}\right] \\ \mathrm{GdL}_{17}\left[\mathrm{~N}\left(\mathrm{SiMe}_{3}\right)_{2}\right] & \\ \mathrm{SmL}_{17}\left[\mathrm{~N}\left(\mathrm{SiMe}_{3}\right)_{2}\right] & \end{array}$

Library 3

$\begin{array}{ll}\mathrm{YbL}_{\mathbf{1 0}}\left[\mathrm{N}\left(\mathrm{SiMe}_{3}\right)_{2}\right] & \mathrm{LaL}_{\mathbf{1 8}}\left[\mathrm{N}\left(\mathrm{SiMe}_{3}\right)_{2}\right] \\ \mathrm{YbL}_{\mathbf{1 9}}\left[\mathrm{N}\left(\mathrm{SiMe}_{3}\right)_{2}\right] & \mathrm{LaL}_{\mathbf{1 9}}\left[\mathrm{N}\left(\mathrm{SiMe}_{3}\right)_{2}\right] \\ \mathrm{YbL}_{\mathbf{2 0}}\left[\mathrm{N}\left(\mathrm{SiMe}_{3}\right)_{2}\right] & \mathrm{LaL}_{\mathbf{2 0}}\left[\mathrm{N}\left(\mathrm{SiMe}_{3}\right)_{2}\right] \\ \mathrm{YbL}_{\mathbf{2 1}}\left[\mathrm{N}\left(\mathrm{SiMe}_{3}\right)_{2}\right] & \mathrm{LaL}_{\mathbf{2 1}}\left[\mathrm{N}\left(\mathrm{SiMe}_{3}\right)_{2}\right]\end{array}$

Table 6 Screening of library 4 for activity

\begin{tabular}{llllr}
\hline Entry & Initiator & Appearance & $\begin{array}{l}{ }^{1} \mathrm{H} \mathrm{NMR} \\
\text { analysis }\end{array}$ & Conv $\%^{a}$ \\
\hline 1 & $\mathrm{LaL}_{9}\left[\mathrm{~N}\left(\mathrm{SiMe}_{3}\right)_{2}\right]$ & Yellow liquid & Monomer & 0 \\
2 & $\mathrm{YL}_{9}\left[\mathrm{~N}\left(\mathrm{SiMe}_{3}\right)_{2}\right]$ & Yellow gel & Polymer & 73 \\
3 & $\mathrm{PrL}_{9}\left[\mathrm{~N}\left(\mathrm{SiMe}_{3}\right)_{2}\right]$ & Yellow liquid & Monomer & 0 \\
4 & $\mathrm{GdL}_{9}\left[\mathrm{~N}\left(\mathrm{SiMe}_{3}\right)_{2}\right]$ & Yellow gel & Polymer & 100 \\
5 & $\mathrm{YbL}_{9}\left[\mathrm{~N}\left(\mathrm{SiMe}_{3}\right)_{2}\right]$ & Yellow liquid & Monomer & 0
\end{tabular}

${ }^{a}$ Obtained from ${ }^{1} \mathrm{H}$ NMR analysis.

the aromatic ring, the complexes are inactive. Sterically demanding groups on the aromatic rings are essential, presumably to prevent metal complex dimerisation and to protect the active site and prevent termination reactions. In addition to the steric demands of the ligand, the type of nitrogen donor was also shown to have a significant effect on the polymerisation activity. If the ligand contains a secondary amine only low conversions (10-30\%) were achieved, even when $\mathrm{R}=$ tert-Pe, possibly due to competing $\mathrm{N}-\mathrm{H}$ activation processes. Low activity was also observed for these ligands when they contained pendant pyridyl donors, possibly due to strong donation of this group to the metal center.

Variation in the central ion size results in substantial differences in activity. $\mathrm{YL}_{1}\left(\mathrm{~N}\left\{\mathrm{SiMe}_{2} \mathrm{H}\right\}_{2}\right)$ and $\mathrm{SmL}_{1}\left(\mathrm{~N}\left\{\mathrm{SiMe}_{3}\right\}_{2}\right)$ give $100 \%$ conversion of monomer to polymer, Table 4. However, the related complexes $\mathrm{LaL}_{\mathbf{1}}\left[\mathrm{N}\left(\mathrm{SiMe}_{2} \mathrm{H}\right)_{2}\right.$ and $\operatorname{Pr}_{\mathbf{1}}\left[\mathrm{N}\left(\mathrm{SiMe}_{3}\right)_{2}\right]$ show no activity. These metals have very different ionic radii $(6$ coordinate species; $\mathrm{Y}^{3+}, 90.0$ pm, $\mathrm{Sm}^{3+}, 95.8$ pm, $\mathrm{Pr}^{3+}, 99.0$ pm, $\left.\mathrm{La}^{3+}, 103.2 \mathrm{pm}\right){ }^{4}$ The larger ion sizes of $\operatorname{Pr}$ and La may allow easier termination, competitive cyclisation reactions, dimerisation of metal containing species or site blockage through irreversible coordination of the caprolactone monomer.

Polymerisations were then attempted using Schiff base ligands, Table 5. Library 2 varied the metal center and kept the ligand constant. However, despite using the bulkiest of the ligands prepared, none of the combinations provided an active initiator. At the same time, library 3 was screened, which varied the ligand and kept the metal center constant. Lanthanum and ytterbium were chosen as they are the largest and smallest lanthanides, respectively. This also contained no active species. In both libraries, reaction with benzyl alcohol yielded lanthanide benzyloxy containing species, but these were also inactive.

\section{Inferences from secondary screening}

Library 4 and Library 5, Tables 6 and 7, were used to confirm the effect of ion size on polymerisation activity, and also the crucial importance of the tert-pentyl groups in facilitating high activities. It can be concluded that Gd and Sm (and possibly Eu, as it is intermediate in size to $\mathrm{Gd}$ and $\mathrm{Sm}$, but was not examined) with $\mathbf{L}_{9}$ are the best combinations of ligand and lanthanide ion to afford moderately active initiators for the polymerisation of $\varepsilon$-caprolactone. These contain a pendant amine. However, Gd with $\mathbf{L}_{12}$, which contains both amines in the backbone of the ligand, gives the narrowest polydispersity but at a lower conversion. This is probably due to the fact 
Table 7 Screening of library 5 for activity

\begin{tabular}{|c|c|c|c|c|c|}
\hline Entry & Initiator & Appearance & ${ }^{1} \mathrm{H}$ NMR analysis & Conv $\%^{a}$ & $M_{\mathrm{w}} / M_{\mathrm{n}}$ \\
\hline 1 & $\operatorname{PrL}_{15}\left[\mathrm{~N}\left(\mathrm{SiMe}_{3}\right)_{2}\right]$ & Yellow liquid & Monomer & 0 & \\
\hline 2 & $\operatorname{PrL}_{12}\left[\mathrm{~N}\left(\mathrm{SiMe}_{3}\right)_{2}\right]$ & Yellow liquid & Monomer & 0 & \\
\hline 3 & $\operatorname{PrL}\left[\mathrm{N}\left(\mathrm{SiMe}_{3}\right)_{2}\right]$ & Yellow liquid & Monomer & 0 & \\
\hline 4 & $\mathrm{SmL}_{15}\left[\mathrm{~N}\left(\mathrm{SiMe}_{3}\right)_{2}\right]$ & Yellow gel & Polymer & 47 & 2.1 \\
\hline 5 & $\mathrm{SmL}_{\mathbf{1 2}}\left[\mathrm{N}\left(\mathrm{SiMe}_{3}\right)_{2}\right]$ & Yellow liquid & Monomer & 0 & \\
\hline 6 & $\mathrm{SmL}_{9}\left[\mathrm{~N}\left(\mathrm{SiMe}_{3}\right)_{2}\right]$ & Off-white solid & Polymer & 100 & 1.2 \\
\hline 7 & $\mathrm{GdL}_{15}\left[\mathrm{~N}\left(\mathrm{SiMe}_{3}\right)_{2}\right]$ & Yellow liquid & Polymer & 20 & \\
\hline 8 & $\mathrm{GdL}_{12}\left[\mathrm{~N}\left(\mathrm{SiMe}_{3}\right)_{2}\right]$ & White solid & Polymer & 67 & 1.1 \\
\hline 9 & $\mathrm{GdL}_{9}\left[\mathrm{~N}\left(\mathrm{SiMe}_{3}\right)_{2}\right]$ & Off-white solid & Polymer & 100 & 1.7 \\
\hline 10 & $\mathrm{YbL}_{15}\left[\mathrm{~N}\left(\mathrm{SiMe}_{3}\right)_{2}\right]$ & Yellow gel & Monomer & 0 & \\
\hline 11 & $\mathrm{YbL}_{12}\left[\mathrm{~N}\left(\mathrm{SiMe}_{3}\right)_{2}\right]$ & Yellow liquid & Monomer & 0 & \\
\hline 12 & $\mathrm{Yb} \mathbf{L}_{9}\left[\mathrm{~N}\left(\mathrm{SiMe}_{3}\right)_{2}\right]$ & Yellow liquid & Monomer & 0 & \\
\hline
\end{tabular}

Table $8 M_{\mathrm{n}}$ and $M_{\mathrm{w}} / M_{\mathrm{n}}$ data for polycaprolactone samples

\begin{tabular}{|c|c|c|}
\hline Initiator & $M_{\mathrm{n}}$ & $M_{\mathrm{w}} / M_{\mathrm{n}}$ \\
\hline $\mathrm{YL}_{1}\left[\mathrm{~N}\left(\mathrm{SiMe}_{2} \mathrm{H}\right)_{2}\right]$ & $\begin{array}{l}46,700 \\
46,400\end{array}$ & 1.6 \\
\hline $\mathrm{YL}_{9}\left[\mathrm{~N}\left(\mathrm{SiMe}_{3}\right)_{2}\right]$ & $\begin{array}{l}13,000 \\
13,100\end{array}$ & 1.2 \\
\hline $\mathrm{YL}_{\mathbf{1 3}}\left[\mathrm{N}\left(\mathrm{SiMe}_{3}\right)_{2}\right]$ & $\begin{array}{l}5,020 \\
5,030\end{array}$ & 1.2 \\
\hline $\mathrm{SmL}_{1}\left[\mathrm{~N}\left(\mathrm{SiMe}_{3}\right)_{2}\right]$ & $\begin{array}{l}40,400 \\
40,800\end{array}$ & 2.1 \\
\hline $\mathrm{SmL}_{9}\left[\mathrm{~N}\left(\mathrm{SiMe}_{3}\right)_{2}\right]$ & $\begin{array}{l}78,100 \\
79,300\end{array}$ & 1.2 \\
\hline $\mathrm{SmL}_{15}\left[\mathrm{~N}\left(\mathrm{SiMe}_{3}\right)_{2}\right]$ & $\begin{array}{l}10,600 \\
11,500\end{array}$ & 2.1 \\
\hline $\mathrm{Gd}_{9}\left[\mathrm{~N}\left(\mathrm{SiMe}_{3}\right)_{2}\right]$ & $\begin{array}{l}70,900 \\
70,100\end{array}$ & 1.7 \\
\hline $\mathrm{GdL}_{12}\left[\mathrm{~N}\left(\mathrm{SiMe}_{3}\right)_{2}\right]$ & $\begin{array}{l}43,400 \\
44,700\end{array}$ & 1.1 \\
\hline
\end{tabular}

that $\mathbf{L}_{12}$ provides better protection of the metal center, preventing transesterification and other termination processes, but also means the active site is less open to incoming monomer units and results in lower conversions. The best combination of conversion and polydispersity is Sm with $\mathbf{L}_{\mathbf{g}}$. Unfortunately, crystals of our most active complexes such as $\mathrm{Gd} \mathbf{L}_{9}\left[\mathrm{~N}\left(\mathrm{SiMe}_{3}\right)_{2}\right]$ suitable for X-ray diffraction analysis have not been grown to date.

The activities of our initiators are comparable with other polymerisation initiators containing sterically demanding ligands..$^{30}$ As expected, the activities of species discovered in this work are considerably less than simple yttrium alkoxides formed in situ from $\mathrm{Y}\left(\mathrm{N}\left\{\mathrm{SiMe}_{3}\right\}_{2}\right)_{3} \cdot{ }^{13}$ However, control of stereochemistry in the polymerisation of other lactones would not be possible with such systems and additional ancillary ligands, possibly related to those described herein, would be necessary.

\section{Polymer characterisation}

The average molecular weights of the polycaprolactone varies from 5,000 to 79,000 (Table 8, Fig. 5). Narrow unimodal molecular weight distributions ranging from 1.1 to 2.1 suggest that the reactions are controlled and imply that only one active species is present. Our initiators probably have a monomeric structure, as related yttrium and lanthanum complexes have recently been structurally characterised. ${ }^{23,48}$ The $M_{\mathrm{w}} / M_{\mathrm{n}}$ values are somewhat higher than those for a living polymerisation and suggest that transesterification takes place to a small extent. However, copolymerisations of $\varepsilon$-caprolactone with $\delta$-valerolactone were successful. End group analysis of the resulting polymers and co-polymers was inconclusive, as $\mathrm{N}\left(\mathrm{SiMe}_{3}\right)_{2}$ resonances were not always detectable. Using one of the most active initiators discovered in this work, $\mathrm{Gd} \mathbf{L}_{9}\left[\mathrm{~N}\left(\mathrm{SiMe}_{3}\right)_{2}\right]$, a linear relationship between the number average molecular weight $\left(M_{\mathrm{n}}\right)$ and $[\mathrm{M}]_{\mathrm{o}} /[\mathrm{I}]_{\mathrm{o}}$ for the polymerisation of $\varepsilon$-caprolactone was observed (see Fig. 6) and provides further evidence for controlled polymerisations. In the most active systems containing $\mathbf{L}_{\mathbf{9 - 1 6}}$, sterically demanding tert-pentyl or tert-butyl groups protect the active site and prevent termination processes. At the same time there is limited access to the active site for the incoming monomer and this leads to lower conversions and lower molecular weight polymers.

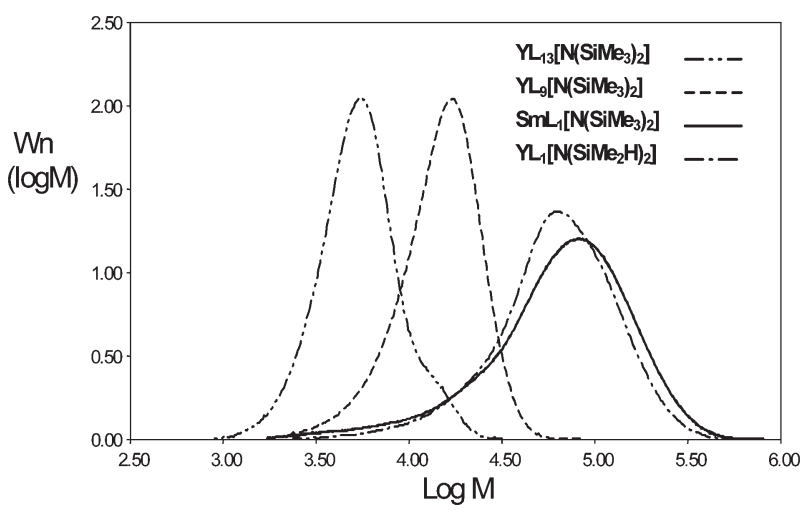

Fig. 5 Selected gel permeation chromatogram curves of poly(caprolactone) obtained with lanthanide based initiators.

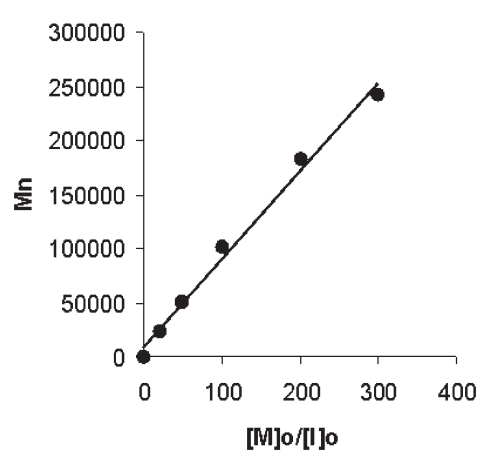

Fig. 6 Plot of $\mathrm{M}_{n}$ (determined by GPC) versus the number of equivalents of $\varepsilon-\mathrm{CL}$; rt, toluene.

\section{Conclusions}

Parallel synthesis of lanthanide complexes offers a route to identifying the most promising metal-ligand combinations for a particular process. An initial screening of 45 lanthanide/group 3 derivatives, of the general form $\mathrm{Ln}(\mathrm{ONNO}) \mathrm{N}\left(\mathrm{SiMe}_{2} \mathrm{R}\right)_{2}$ where $\mathrm{R}=\mathrm{H}$ or $\mathrm{Me}$ and $\mathrm{Ln}=\mathrm{Y}, \mathrm{La}, \mathrm{Pr}, \mathrm{Sm}, \mathrm{Gd}$ or $\mathrm{Yb}$, for caprolactone polymerisation activity highlighted several features worthy of further investigation. Ligands containing disubstituted tert-pentyl aryl rings afforded initiators capable of performing controlled polymerisation of $\varepsilon$-caprolactone. Much work remains to be done but this initial foray into high-throughput methods clearly demonstrates the use of this technique in lanthanide catalysis and also in the polymerisation of monomers other than olefins. This approach will be extended to lanthanide systems for other processes such as acrylate polymerisation and co-polymerisations. 


\section{Acknowledgements}

We thank the Royal Society (Research Grant and University Research Fellowship, F. M. K.) and the EPSRC (Studentship, C. E. W.) for generous funding. RAPRA Technology Ltd. are acknowledged for GPC analyses and Richard Lindup (University of York) for assistance with variable temperature NMR experiments.

\section{References}

1 S. Kobayashi, Lanthanides: Chemistry and Use in Organic Synthesis, Springer, Berlin, 1999.

2 Z. Hou and Y. Wakatsuki, Coord. Chem. Rev., 2002, 231, 1.

3 W. E. Piers and D. J. H. Emslie, Coord. Chem. Rev., 2002, 233-234, 131.

4 R. D. Shannon, Acta Crystallogr., Sect. A: Cryst. Phys., Diffr., Theor Gen. Cryst., 1976, A32, 751.

5 M. D. Fryzuk, L. Jafarpour, F. M. Kerton, J. B. Love, B. O. Patrick and S. J. Rettig, Organometallics, 2001, 20, 1387.

6 W. J. Evans, R. A. Keyer and J. W. Ziller, Organometallics, 1993, 12, 2618.

7 C. M. Forsyth, S. P. Nolan, C. L. Stern, T. J. Marks and A. L. Rheingold, Organometallics, 1993, 12, 3618 .

8 S. Agarwal and M. Puchner, Eur. Polym. J., 2002, 38, 2365.

9 J. Eppinger, M. Spiegler, W. Hieringer, W. A. Herrmann and R. Anwander, J. Am. Chem. Soc., 2000, 122, 3080.

10 B. J. O'Keefe, M. A. Hillmyer and W. B. Tolman, J. Chem. Soc., Dalton Trans., 2001, 2215 and references therein.

11 M. Endo, T. Aida and S. Inoue, Macromolecules, 1987, 20, 2982.

12 W. J. Evans and H. Katsumata, Macromolecules, 1994, 27, 2330.

13 E. Martin, P. Dubois and R. Jerome, Macromolecules, 2003, 36, 5934.

14 L. M. Alcazar-Roman, B. J. O'Keefe, M. A. Hillmyer and W. B. Tolman, Dalton Trans., 2003, 3082.

15 K. Nakano, N. Kosaka, T. Hiyama and K. Nozaki, Dalton Trans., 2003, 4039 .

16 S. M. Guillaume, M. Schappacher and A. Soum, Macromolecules, 2003, 36, 54

17 B. J. O'Keefe, L. E. Breyfogle, M. A. Hillmyer and W. B. Tolman, J. Am. Chem. Soc., 2002, 124, 4384

18 P. W. Roesky, M. T. Gamer, M. Puchner and A. Greiner, Chem. Eur. J., $2002,8,5265$.

19 M. L. Hsueh, B. H. Huang and C. C. Lin, Macromolecules, 2002, 35, 5763.

20 P. Ravi, T. Grob, K. Dehnicke and A. Greiner, Macromolecules, 2001, 34, 8649 .

21 P. Ravi, T. Grob, K. Dehnicke and A. Greiner, Macromol. Chem. Phys., 2001, 202, 2641 .

22 B. M. Chamberlain, B. A. Jazdzewski, M. Pink, M. A. Hillmyer and W. B. Tolman, Macromolecules, 2000, 33, 3970.

23 C.-X. Cai, L. Toupet, C. W. Lehmann and J.-F. Carpentier, J. Organomet. Chem., 2003, 683, 131.

24 D. Chakraborty and E. Y.-X. Chen, Organometallics, 2003, 22, 769.

25 M. Deng, Y. Yao, Q. Shen, Y. Zhang and J. Sun, Dalton Trans., 2004, 944.

26 T. Grob, G. Seybert, W. Massa, F. Weller, R. Palaniswami, A. Greiner and K. Dehnicke, Angew. Chem., Int. Ed. Engl., 2000, 39, 4373.

27 C. Jing-Lei, Y. Ying-Ming, L. Yun-Jie, Z. Li-Ying, Z. Yong and S. Qi, J. Organomet. Chem., 2004, 689, 1019 .

28 S. C. F. Kui, H.-W. Li and H. K. Lee, Inorg. Chem., 2003, 42, 2824

29 J. Ling, W. Zhu and Z. Shen, Macromolecules, 2004, 37, 758.

30 Y.-C. Lui, B.-T. Ko and C.-C. Lin, Macromolecules, 2001, 34, 6196.

31 Y. Luo, P. Selvam, Y. Ito, S. Takami, M. Kubo, A. Imamura and A. Miyamoto, Organometallics, 2003, 22, 2181.

32 Y. Matsuo, K. Mashima and K. Tani, Organometallics, 2001, 20, 3510.

33 M. Nishiura, Z. Hou, T. Koizumi, T. Imamoto and Y. Wakatsuki, Macromolecules, 1999, 32, 8245.
34 J. Okuda and I. L. Rushkin, Macromolecules, 1993, 26, 5530.

35 R.-C. Yu, C.-H. Hung, J.-H. Huang, H.-Y. Lee and J.-T. Chen, Inorg. Chem., 2002, 41, 6450.

36 M. Schapper, T. Fabre, A. F. Mingotaud and A. Soum, Biomaterials, 2001, 22, 2849.

37 Y. Shen, Z. Shen, Y. Zhang and K. Yao, Macromolecules, 1996, 29, 8289.

38 Y. Shen, Z. Shen, J. Shen, Y. Zhang and K. Yao, Macromolecules, 1996, 29, 3441 .

39 M. Visseaux, C.-H. Brachais, C. Boisson and K. Tortosa, C. R. Acad. Sci. Paris, Ser. IIc: Chim., 2000, 3, 631.

40 M. Vivas and J. Contreras, Eur. Polym. J., 2003, 39, 43.

41 M. Yamashita, Y. Takemoto, E. Ihara and H. Yasuda, Macromolecules, 1996, 29, 1798

42 Y. Yao, Y. Luo, J. Chen, Z. Zhang, Y. Zhang and Q. Shen, J. Organomet. Chem., 2003, 679, 229.

43 Y. Satoh, N. Ikitake, Y. Nakayama, S. Okuno and H. Yasuda, J. Organomet. Chem., 2003, 667, 42.

44 Y. Takashima, Y. Nakayama, K. Watenabe, T. Itono, N. Ueyama, A. Nakamura, H. Yasuda and A. Harada, Macromolecules, 2002, 35, 7538.

45 Y. Wang, S. Onozawa and M. Kunioka, Green Chem., 2003, 5, 571.

46 M. S. Hill and P. B. Hitchcock, J. Chem. Soc., Dalton Trans., 2002, 4694.

47 H. Ma, T. P. Spaniol and J. Okuda, Dalton Trans., 2003, 4770.

48 C.-X. Cai, A. Abderramane, C. W. Lehmann and J.-F. Carpentier, Chem. Commun., 2004, 330.

49 P. Hormnirun, E. L Marshall, V. C. Gibson, A. J. P. White and D. J. Williams, J. Am. Chem. Soc., 2004, 126, 2688.

50 S. Dahmen and S. Brase, Synthesis, 2001, 10, 1431.

51 R. H. Crabtree, Chem. Commun., 1999, 1611.

52 J. G. de Vries and A. H. M. de Vries, Eur. J. Org. Chem., 2003, 799.

53 T. R. Boussie, G. M. Diamond, C. Goh, K. A. Hall, A. M. LaPointe, M. Leclerc, C. Lund, V. Murphy, J. A. W. Shoemaker, U. Tracht, H. Turner, J. Zhang, T. Uno, R. K. Rosen and J. C. Stevens, J. Am. Chem. Soc., 2003, 125, 4306.

54 D. J. Jones, V. C. Gibson, S. M. Green and P. J. Maddox, Chem. Commun., 2002, 1038.

55 J. Tian and G. W. Coates, Angew. Chem., Int. Ed. Engl., 2000, 39, 3626.

56 V. Murphy, X. Bei, T. Boussie, O. Brummer, G. Diamond, C. Goh, K. Hall, A. Lapointe, M. Leclerc, J. Longmire, J. Shoemaker, H. Turner and W. H. Weinberg, Chem. Rec., 2002, 2, 278.

57 N. Adams, H. J. Arts, P. D. Bolton, D. Cowell, S. R. Dubberley, N. Friederichs, C. M. Grant, M. Kranenburg, A. J. Sealey, B. Wang, P. J. Wilson, A. R. Cowley, P. Mountford and M. Schroder, Chem. Commun., 2004, 434.

58 T. Berg, A. Simeonov and K. D. Janda, J. Comb. Chem., 1999, 1, 96.

59 E. Y. Tshuva, I. Goldberg and M. Kol, Organometallics, 2001, 20, 3017.

60 W. E. Piers, P. J. Shapiro, E. E. Bunel and J. E. Bercaw, Synlett, 1990, 74.

61 D. C. Bradley, J. S. Ghotra and F. A. Hart, J. Chem. Soc., Dalton Trans., 1973, 1021.

62 J. F. Larrow and E. N. Jacobsen, J. Org. Chem, 1994, 59, 1939.

63 SMART v5.625, Program for Data Collection on Area Detectors, Bruker Analytical X-ray Systems, Madison, WI, USA.

64 SAINT Software Users Guide, Version 6.22, Bruker Analytical X-ray Systems, Madison, WI, USA.

65 G. M. Sheldrick, SADABS v2.03: Area-Detector Absorption Correction, University of Göttingen, Germany, 1999.

66 G. M. Sheldrick, SHELXS-97, Program for the Solution of Crystal Structures, University of Göttingen, Germany, 1997.

67 G. M. Sheldrick, SHELXL-97, Program for the Refinement of Crystal Structures, University of Göttingen, Germany, 1997.

68 H. W. Gorlitzer, M. Spiegler and R. Anwander, J. Chem. Soc., Dalton Trans., 1999, 4287. 